\title{
Sex vs Gender: Are We there Yet? A Biological Location for Gender, not Sex.
}

Author: Bobbi Tannett

\section{ABSTRACT}

Research to date has left unexplained what may seem indefinable - gender identity. This article synthesizes important research that has not previously presented a case for a biological location of gender in the human phenotype. While gonadal sex and sexual orientation are accepted as emanating from genetic and hormonal templates, gender's existence currently has so far emanated from a nebulous 'somewhere' in the brain.

Recent hypotheses have argued there is no natural dichotomy of gendered behavior and proposed a merging of otherwise distinct categories for sex and gender into a mosaic of sex/gender (Joel \& McCarthy, 2017; Joel et al. 2016; Joel, 2011). However, this seems to detour around nonphysical behavior relevant to reproduction. 
This paper makes an original case for the sense of gender as neurophysiological and specifically centered within the reproductive axis. This fits in well with this current understanding of genetic, hormonal, and environmental influences on sexual identity (Joel et al., 2020) and with the earlier biopsycho-social approach (Eagly \& Wood, 2013) now favored in research into identity diversity.

\section{INTRODUCTION}

Until recently, two sexes and two genders were the unshakable and universal components of Western societies, often ferociously enforced. As centuriesold compulsory categories, they had been unproblematic in the fabric of the everyday, at least for those who conformed.

Professional and non-professional articles alike often present gender as a person's sense of self and centered in the brain, but don't venture to suggest where in the brain. This article presents the case for gender's biological origins in dimorphic interconnected networks of the reproductive axis and canalized towards dominant reproductive endpoints. 
This paper proposes the signature of a gendered self emanates from innate differential tendencies stemming from the interconnected networks of the reproductive axis that process the physical and cognitive behaviours relevant to reproduction.

Recent research has argued there is no natural dichotomy of gendered behavior and proposed the notional merging of otherwise distinct categories for sex and gender into a mosaic of sex/gender. However, this seems to disregard non-physical behavior relevant to reproduction. Further, it also disregards, for example, transgender children who persist post-puberty with a gender opposite to their bodily sex, and whose later reproductive behavior is not always conventional for their bodily sex. The presentation of differential cognitive behavior separate to physical reproductive behavior, and lessons from the intersex and transgender communities, arguably makes the notion of a single category of sex/gender awkward.

\section{NON-BINARY BEHAVIOUR}

As centuries-old compulsory categories, two sexes and two genders have been unproblematic in the fabric of the everyday, at least for those who 
conform. However, the notion of 'a gendered self' only seems explicable philosophically. Certainly the brain is considered the anatomical location for gender (Bao \& Swaab, 2011), nonetheless, questions remain; from what, and perhaps from where specifically could a gendered self emanate?

By age two to three, most children have an awareness of their gender (Ahmed et al., 2004), and most all, without issue. A very few, on the other hand, feel a sense of unease. We now refer to this unease as gender dysphoria (GD) (Sánchez \& Vilain, 2013). Not to forgo mature-age onset dysphoric individuals whose earliest memories are filled with similar unease, this article's search for gender speaks more directly to the question of explaining the persistent feelings of GD in very young children, those who have not had sufficient time to learn the nuances or politics of sex and gender?

Parallel with the fact that females menstruate, ovulate, fall pregnant, deliver, lactate, and males do not, necessitating dimorphic brain regions to regulate these diverse processes (McCarthy \& Konkle, 2005), this article will present a parallel case for the internal and perceptual sense or feeling 
of gender (Fiani, 2018) as associated with reproductive physiology and behavior primarily centered in the prefrontal cortex (PFC) and limbic system of the reproductive axis. These regions are significantly differentiated between the sexes (Lenschow \& Lima, 2020; Ritchie et al., 2018; Pavolova, 2017; Reber \& Tranel, 2017; Guillamon, Junque, \& Gómez-Gil, 2016).

In discussing dimorphic brain structure, brain function, sex, and gender, language matters (Joel \& Fausto-Sterling, 2016). The terms 'sex' and 'gender' remain actively entangled with each other, and neuroscience has not provided a reasoned account for where sex ends and gender begins (Kaiser, 2012). In this vein, incorporation of the terms sex and gender into a mosaic notion of sex/gender has been proposed (Joel \& McCarthy, 2017; Rippon et al., 2014).

\section{Sex / gender}

Professional and non-professional articles often present gender as a person's sense-of-self within several intersecting factors and influences (Gliske, 2019; Fiani, 2018; Strauss et al., 2017), however, no one has ventured to suggest what the 'factors' that 
make gender are, nor where they source.

Arguments for the merger of 'sex' and 'gender' favor we desist labelling them as separate variables and combine them into the singular term 'sex/gender' (Kaiser, 2012), or 'gender/sex' (van Anders, 2015).

No matter which is regarded the default state for human embryos, male or female (Joel et al., 2020), the high function areas of the brain have been labelled initially intersex and not dimorphic (Hyde et al., 2018). Indeed, levels of intelligence do not appear sexually dimorphic but rather are a mosaic (Joel \& McCarthy, 2017; Jones \& Lopez, 2014). The notion of human behavioral overlap or mosaic may theoretically remove the need to separate the terms sex and gender, yet the idea that prenatal brains are intersexed in vivo and belong to a single heterogeneous population is an enormous ambition according to Pavlova (2017). Is this debate now over, or can we continue to argue for a sense of gender biologically separate from body that is dimorphic yet canalized?

Although the 'characteristics' of 'sex-related behavior' relative to the physicality of reproduction are clearly dimorphic, other sex-related behaviours 
have not been explicitly identified. While some see gender as 'subconscious sex' and an intrinsic part of an individual that hardwires traits of one sex or the other into the brain (Serano, 2016), apart from physical behaviours related to mating, clarification of these 'behaviours' and 'traits' is missing.

In contrast, this article has not abandoned dimorphic differences, and presents sex, gender, and behavior as canalized (Sisk, 2016; Mustanski et al., 2005) into those domains relevant to reproduction. Notably, the behavioral domain is split further from the general cognitive mosaic of functions such as reasoning, organization, and execution of complex thoughts, to those related specifically to reproduction.

\section{WHAT IS GENDER THEN?}

This article presents gender a the perpetual neurophysiological signature associated with the interconnected networks of the reproductive axis, i.e., a conscious awareness of the neurophysiology from brain areas processing cognitive behavior related to reproduction; many of these behaviors are presented as dimorphic, i.e., gendered, though not strictly. 
The brain areas processing cognitive behavior related to reproduction are incorporated within the dimorphic reproductive axis. In other words, these behaviors are gendered and may be reinforced or not by outside factors such as culture and social learning. This article will first discuss the reproductive axis, then the cognitive behaviors differentially associated with this axis as the source of innate gender.

\section{REPRODUCTIVE AXIS}

The reproduction axis stems from the testes, ovaries, on to the limbic system. The axis is a tightly regulated feedback loop paramount to reproductive potential (Acevedo-Rodriguez et al. 2018; Couse et al. 2003). Neuroendocrine control of this axis rests with a group of neurons called gonadotropin-releasing hormone $(\mathrm{GnRH})$ neurons dispersed in the part of the limbic system within the axis known as the hypothalamus (Alzahrani et al., 2019). The axis further coordinates folliclestimulating hormone (FSH) and luteinizing hormone (LH) from the anterior pituitary, and the sex steroids estrogen, progesterone, and androgens, produced primarily by the ovary, corpus luteum, and adrenals (Blair et al., 2015; Klein, 2003). 
Significantly, estrogen and androgen receptors show high levels of distribution in the pituitary, hypothalamus, amygdala, ovaries, testes, and uterus (Denley et al., 2018; Swaab, 2004; Sato et al., 2004; McEwen, 2001), in other words, in the reproductive axis overall.

Disruption of this axis prenatally and during minipuberty (the 3-6 post-natal months) can lead to sexually dimorphic changes in linear growth, genital growth, and anabolic changes in body composition (Rogol, 2020; Kurtoğlu \& Baştuğ, 2014) that may result in disorders of sexual development (DSD) (Legato, 2018). A subsystem of this axis is the limbic system (Legato, 2018).

\section{The Limbic System}

The limbic system, first described in 1964, is one of the most studied functional networks in the social brain (Yang, Comninos, \& Dhillo, 2018). The zones of the limbic system develop differentially (Zaidi, 2010; Sakata \& Crews, 2004; Kruijver et al., 2000) and are stable across the lifespan (Simerly, 2010, 2002; McCarthy \& Konkle, 2005). There are suggested interlinked neural pathways through which limbic structures may influence human 
behavior (Bègue et al., 2019). The main components of the limbic system are the hippocampus, the amygdala, and the hypothalamus (Roxo et al., 2011).

Differences in the hippocampus (Ristori et al., 2020; Jones \& Lopez, 2014; Sundermann et al., 2010), hypothalamus (Denley et al., 2018;

Mhaouty-Kodja et al., 2018; Xu et al., 2012;

Sandremann et al., 2010), and amygdala (MhaoutyKodja et al., 2018; Jones \& Lopez, 2014; Cooke et al., 2007) are repeatedly shown to be dimorphic in postmortem and in vivo imaging studies (BaldingerMelich et al., 2020).

The pituitary gland, while not physically a region of the limbic system, is a master gland regulating hormone levels in the body. The hormones of the pituitary gland send signals to the thyroid gland, adrenal gland, ovaries and testicles to stimulate or inhibit their hormone production. Consistent with prior research, non-linear associations between age and pituitary gland volume differ by sex (Whittle et al., 2020).

Hormones integral to developmental stages not only mediate physiological and endocrine processes 
involved in reproduction but also act as neuromodulators within limbic brain centers to facilitate the expression of innate emotions and behaviours required for reproduction (Yang et al., 2018; Kawakami et al., 1967).

\section{Reproductive Behavior}

More strikingly, many cognitive behaviors differentially associated with the limbic system (Hoffman, 2013; Bonelli \& Cummings, 2007) are relevant to reproduction as part of an integrated network of intrinsic links that unite sex, emotion, and reproduction to facilitate species survival (Yao et al., 2017). For example, emotion processing and motivation (Tunc et al., 2016), face recognition, aggression, sexual arousal, anxiety, and fear conditioning (Marwha et al., 2017; Heberlein et al., 2008; Swain et al., 2007).

And so the sex of an individual significantly modulates behaviors related to reproduction and many cognitive behaviors associated with the limbic system and reproduction are canalized towards male and female endpoints. 


\section{Other cerebral regions relevant to reproduction}

In terms of cerebral texture analysis via threedimensional magnetic resonance imaging, Tunc presented differences in connectivity between multiple brain regions as clear evidence for a basis to behavioral differences between males and females (Tunc et al., 2016). The pre-frontal cortex (PFC) is involved in the generation of dimorphic behaviours and with its subcortical connections in the limbic system, the PFC is a neurological structure heavily involved in the social brain (Ritchie et al., 2018; Pavlova, 2017; Reber \& Tranel, 2017; Guillamon et al., 2016).

\section{CANALIZED REPRODUCTIVE BEHAVIOR}

The canalization of behaviors associated with reproduction is unsurprising in any sexually dimorphic reproducing species. The greatest and most stable gender differences occur in only several areas: a few motor behaviours based on physicality, some aspects of sexuality, and the cognitive areas of aggression, verbal ability, visual-spatial ability, mathematical ability, and empathy (Swain et al., 2007; Hyde, 2005; Maccoby \& Jacklin, 1974).

These behaviours originating from an 
interconnecting mosaic (as opposed to the general behavioral mosaic of psychology) of the cortex (pre-frontal lobes), and reproductive axis (limbic system) are heavily involved in cognitive functions related to survival and reproduction (Hoffmann, 2013).

Incumbent in reproductive fitness are behaviours involved in courtship, mating, care of offspring, territorial defense, and resource gathering. These differential co-dependent behaviors exist in pair bonding, cooperation and competition, spatial ability and linguistic ability, connectedness and disconnectedness, group activities and individual activities, and nurturant activities (Lenschow \& Lima, 2020; Dulac et al., 2014; Sokolowski \& Corbin, 2012).

The dominant or aggressive behaviours are associated with cues of capacity to provide expedient resources or to inflict immediate harm onto others, and are thought to be important for males (how aggression can be expressed in terms of reproduction is discussed later in this current article). The emotional behaviours most associated with females are cues of trustworthiness (Whittle et al., 2011), and empathy (Swain et al., 2007). The 
remainder, including levels of intelligence, are a mosaic (Joel \& McCarthy, 2017; Jones \& Lopez, 2014). Women tend toward better social and linguistic skills, while men tend toward higher physical abilities combined with technical, spatial, and navigating (Tay et al., 2019). Inborn essentially driven behavioral differences in the brain are thus limited to factors surrounding reproduction (Stam et al., 2019; Joel \& McCarthy, 2017; Arnold et al., 2004).

Significant behavioral differences stemming from the brain regions previously discussed, can be related to maximizing economic opportunity for pregnant and lactating women and their offspring and incumbent on sexuality, courtship, mating, nurturance and empathy, frequent territorial defense, and resource gathering that characterizes ours and other species (Meyer-Bahlburg, 2019; Unger et al., 2015). The association of these reproductive related behaviors with care of offspring are clear and the significant differences in the arenas of sexuality, aggression, and care of offspring are arguably the most relevant to overall reproductive success for men and women. 


\section{Sexuality}

Under the broader neo analytic understanding gained from the feminist theory of Nancy

Chodorow, we may view sexuality in relation to reproduction, a universal and enduring element of the sexual division of [reproduction] (Chodorow, 1999). This does not negate Freud's view that sexuality was primarily about bonding ahead of reproduction (Freud, 1966). Mothering and fathering are tethered to courtship that is tethered to mating behavior, which is, in turn, is tethered to care of offspring. As such, this broader sexuality is relative to reproductive roles, as others have suggested (Pfaff, 2011; Owen-Blakemore et al., 2009; Bartky, 1999; Buss, 1995).

Greater than trivial behavior differences have been presented in the arenas of aggression and sexuality (Hyde et al., 2018), courtship and care of offspring (Meyer-Bahlburg, 2019). These moderate to large gender differences are notable exceptions to the similarities hypothesis on sex differences and of specific bearing to this article under the umbrella of 'reproductive behaviours.' 


\section{Courtship / mating behavior}

In humans, despite the myth-like belief that males seek sexual intimacy over emotional intimacy, and women the reverse, there is evidence women and men exhibited similar desires (Perrin et al., 2011), although the pursuit of the same may differ (Sakata $\&$ Crews, 2004).

Sex-specific social behavior depends on sexually dimorphic circuitry in the limbic system that processes hormonal, environmental, and experiential information (Newman, 1999), and the behaviours relevant to reproduction are enhanced or not differentially between the sexes by this experiential social learning (Sisk, 2016), nevertheless, the physicality of mating per see is not the topic of this article.

\section{Care of offspring}

Behaviors directed toward young offspring exhibiting striking sex differences in mice and the major roles for the medial amygdala have been demonstrated in the sexually dimorphic control of parenting behaviors (Chen et al., 2019). 
Differences between the sexes for emotional processing are well-acknowledged (Kreukels \& Guillamon, 2016). Behaviours related to reproduction are recognizable in differences in the levels of responses such as sociability, attachment, sentimentality (Stam et al., 2019), aggression (Zell et al., 2015), in defend or befriend (Hoekzema et al., 2017; Sokolowski \& Corbin, 2012; McCarthy et al., 2012; Pearson et al., 2009; Zietsch et al., 2008), instinct (Sweatt et al., 2013), and significantly empathy (Swain et al., 2007).

Sex differences in emotion processing represent one of the most robust sex stereotypes worldwide (Whittle et al., 2020). The limbic system (the emotional nervous system), specifically the subcortical systems including the amygdala, hypothalamus, and hippocampus, have been associated with emotion processing and motivation (Tunc et al., 2016). Females tend to exhibit superior performance in verbal and social proficiency, emotion recognition, and empathy (Kret \& De Gelder, 2012; Kopsida et al., 2009). Women score higher and favor activity involving relationships, and men favor activity involving things (Zell et al., 2015; Del Guidice et al., 2012). 
Arguably, all such behaviors are strongly associated with the reproductive axis and reproductive roles.

\section{Empathy}

Females tend to present higher social awareness and social skills in addition to emotional sensitivity compared with males; women are more empathic (Grabowska, 2017). Empathy is an especially important emotion in infant nurturant and caregiving (Grabowska, 2017; Swain et al., 2007). Empathy can be defined as appropriate perception, experience, and response to another's emotion (Swain et al., 2007), in short, it is the ability to identify and respond to another's mental state and in the care of offspring, it is the ability to respond to infant cues. Human babies are helpless for many years and a mother must resonate with the state of her infant's helplessness, meaning she must possess empathy and maternal synchrony (Leon, 2008; Cardinal et al., 2002; Oxley \& Fleming, 2000).

There are several contributions consistent with sex differences in empathy, both theoretical (Chodorow, 1999; Gilligan, 1993; Freud, 1966), and empirical (Hines, 2017; Swain et al., 2007; Chapman et al., 2006; Hyde, 2005). Gilligan argued that males and 
females speak in a different moral voice. Males adopt more selfish-ness, while females embrace more self-less-ness (Gilligan, 1993). Gender differences in moral reasoning based on care are higher in women, while men's moral reasoning is more based on justice. In terms of statistical effect size, these differences are small (Hyde, 2005), yet considering differences are likely context-dependent across domains (Del Guidice et al., 2012), small gender differences should not be regarded as trivial (Zell et al., 2015).

In line with innate motherly behavioral tendencies and intuition, newborn girls just a few hours old show more interest in human faces, and more sensitivity to tactile, oral, and visual stimuli. This intuition is a basic, immediate, or primitive 'something' that we may see as part of the female self (Gliske, 2019). Although there is the caveat that some behavioral differences could be due to differences in the treatment of newborn boys and girls, even within the first few hours after birth (Jones \& Lopez, 2014). Nonetheless, considering differences as taxonomic and produced regardless of how a child is raised, nurture may merely 
influence the average degree of innate canalized difference (Sisk, 2016; Mustanski et al., 2005).

Changes in levels of female hormones such as estrogen, progesterone, and prolactin through pregnancy have long been implicated in the regulation of maternal behavior (Dulac et al., 2014). Care of dependent offspring subsumes attachment, suckling, and emotional nurturance. The higher levels of empathy shown in females are likely the 'why women mother' that Chodorow was missing (Chodorow, 1999), whereas fathers predominate in other areas of care.

For fathers, care may involve physical aggression in the forms of territorial defense and acquisition of resources (Meyer-Bahlburg, 2019). i.e., the view of aggression outlined below. Human babies and their mothers require security and support in resources for many years, and a father must resonate with the state of his family's needs.

\section{Aggression}

The discrepancy in levels of aggression between men and women is salient. Gonadal steroid levels are increased in a sex-specific manner; testosterone levels peak in boys at 1-3 months of age and 
decline at six months of age (Kuiri-Hänninen et al., 2014). During the fourth to fifth month of pregnancy a surge of fetal testosterone occurs lasting a few weeks to reach adult levels that inundate the male brain inducing anatomical and organizational changes (Batrinos, 2012). Levels of male empathy appear to be reduced by the higher testosterone exposure in-utero (Hines, 2017).

The components of the neural network that regulate aggressive behavior include the amygdala, the hypothalamus, and the orbitofrontal cortex (Gouveia et al., 2019; Unger et al., 2015), all of which are noted as being sexually differential. Testosterone plays a significant role in the arousal of these behavioral manifestations in the brain centers involved in aggression and on to the development of the muscular system that enables their realization. It acts through the interplay between subcortical structures in the amygdala and the hypothalamus (Unger et al., 2015; Batrinos, 2012).

In a study of same-sex (SS) and opposite-sex (OS) twins, OS girls (girls from boy/girl twin sets) showed a more masculine pattern of aggression behavior than did SS girls (girls from girl/girl twin 
sets) with no differences in testosterone levels or pubertal status. The twin study supports prenatal levels of testosterone as higher for OS girls and adds support for sex differences in aggression overall, similar to congenital adrenal hyperplasia (CAH) girls who show more aggression than noneffected siblings (Cohen-Bendahan et al., 2005). The authors suggest the high levels of testosterone coming from the twin male fetuses leads to higher levels of aggression in the OS girls.

Aggressive behavior is a primitive social conduct typical of ancient Anthropocenes that was essential for individuals to compete for food, territory, and mating (Gouveia et al., 2019). Males of the modern Anthropocene are still more likely to exhibit higher levels of visuospatial and navigational skills, as well as direct aggression (Kopsida et al., 2009). Boys tend to enact more direct aggression than girls (Card et al., 2008). Aggression, and not empathy, can be formally studied to the level of Ph.D. in the form of 'War Studies' (Kings College, London). Males score higher than females on measures of aggression (Hyde et al., 2018), spatial processing [resource attainment] (Reber \& Tranel, 2017; Hyde, 2005). Moreover, the magnitude of the difference is 
the largest favoring males in situations with the most danger (Hyde, 2005).

It is not a long bow to regarded aggression as a special kind of natural selection for characteristics that enhance mating ability, survival, and reproductive success. Following Huber and Kravitz (2010), contemporary aggression can be viewed more helpfully, less aberrant, and more positively as heroics or a competitive spirit related to mate selection, self-defense, supply and defense of resources, and defense of significant others.

A philosophical view of aggression presents masculinity as manifesting itself in cruelty and violence where no peace negotiations or arguments in favor of tolerance can decrease its aggression (Weigel, et al., 2020). Within the $21^{\text {st }}$-century 'Anthropocene', such an aberrant masculinity is nonessential (Meyer-Bahlburg, 2019); nonetheless, aggression has not yet evolved out of our species, perhaps simply because aggression is nowadays aligned more positively with 'heroics, a competitive spirit related to mate selection, supply and defense of resources' etcetera.' Unfortunately, as with all human behaviours, some individuals and societies misuse their natural tendencies. 


\section{In Sum}

Sexually dimorphic courtship is tethered to sexually dimorphic mating behavior, which is tethered to sexually dimorphic Mothering and Fathering, which is, in turn tethered to dimorphic roles in the care of offspring. These differential networks are reflected in the dimorphic behaviours relevant to reproduction stemming from the reproductive axis. This article supports the subconscious awareness of this differential is what we refer to as gender.

\section{LESSONS FROM GENDER INCONGRUENCE}

Studies in transgender populations reveal a developmental disconnect between bodily sex (sex) and brain sex (gender). Two thirds of participants in one such study reported feelings of gender incongruence aged 10 or under, and one third aged 5 or under (Diamond, 2013). Following the longestablished scientific principle that to understand the 'usual' one must understand the 'unusual,' we may ask what and where is it transgender people of all ages feel is inconsistent with their biological sex? What is it many children identify as their gender as early as age two (Zucker et al., 1997), or 
age three (Olson \& Gülgöz, 2018; Hewitt et al., 2012).

If gender is an entirely social construct, all hair and makeup as has been implied (Rippon, 2017; Butler, 1990), age six months to five years seems insufficient time to learn the politics and sociocultural structures of gender without some prior form of influence. Indeed there is little evidence that gender nonconforming children have been encouraged or taught to behave differently; rather, childhood gender nonconformity typically emerges despite conventional socialization (Bailey et al., 2016). Furthermore, there is no evidence that the postnatal social environment plays a role in gender identity formation (Bao \& Swaab, 2011).

The dimorphic sexual brain is a substrate of psychosexual development, and the main determinants of cerebral differentiation are likely multimorphic. Genetic and hormonal influences have all been proposed (Ristori et al., 2020; Gliske, 2019; Legato, 2018). Further highlighting the possible developmental disconnect between sex and gender, sexual differentiation of the genitals takes place before sexual differentiation of the brain, 
making it possible that they are not always congruent (Tasopoulos, 2018; Roselli, 2018).

\section{Incongruence}

Evidence for the role of the prenatal organization of the brain in the development of gender incongruence is increasing, although twin studies have not supplied a specific genetic involvement, and the evidence on hormonal involvement is unclear. Genes may play a role very early in development, and it may be the case that hormones simply reinforce an already established gender identity (Legato, 2018). Nonetheless, within transgender studies, the pre-frontal cortex (Kreukels \& Guillamon, 2016), hippocampus (Manzouri et al., 2017; Smith et al., 2015), amygdala (Beking, et al., 2020; Manzouri et al., 2017), hypothalamus (Guillamon et al., 2016; Bao \& Swaab, 2011; Swaab \& Garcia-Falgueras, 2009), epigenetics (Bailey et al., 2016; Diamond, 2013; Rice et al., 2012), and hormones (Ristori et al., 2020;

Fernandez et. al. 2018; Kreukels \& Guillamon, 2016) have all been implicated in their incongruence. 
These implications provide further support for the probability that these regions form a neural location for gender physically and temporally separate to body sex, at least in part.

\section{Persisters and Desisters.}

While debates about the validity of labeling children as persisters and desisters have been prominent (Temple-Newhook et al., 2018; Zucker, 2018), this article asks if there is no internal locus for gender identity, then what is it very young and persisting adult transgender individuals feel is inconsistent with their bodily sex?

Although social learning of male and female differences may begin at birth (Zuloaga et al., 2010), or earlier if the sex of a child is known antenatally, most children express their sense of gender and correctly label that of others by age two or three (Ahmed et al., 2004; Leinbach \& Fagot, 1986). Pre-puberty (ages 3-12) is arguably a time when most gender opposite children, with or without any dysphoria, have not necessarily had sufficient time to comprehend their dissonance nor any competing script to how they feel and behave, and especially in the very young. Furthermore, pre- 
pubescent children who experience GD and continue to do so after puberty (persisters), do not appear to be affected by the usual sex hormone activation of puberty (Guillamon et al., 2016).

Crucially, the 'desisters' do not number $100 \%$ and the notional merging into sex/gender of otherwise distinct canalizations of sex and gender and claims that gender is totally a social construct, seem to ignore very young pre-pubescent transgender children who persist post-puberty with a gender opposite to their bodily sex.

\section{DISCUSSION}

It is challenging to unravel the function of neural circuitry in general (de Vries \& Södersten, 2009). Linking relatively consistent sex differences in brain structure to more fickle sex differences in brain function highlights just how difficult it is. Unravelling sex and gender discussions become even more complicated when differences are context-dependent across domains (Del Giudice et al., 2012), or may not be acted upon until adolescent hormones kick in (Jones \& Lopez, 2014), or even not acted upon until later mechanisms in adulthood 
come into play, as evident in transgender individuals with mature-age onset GD.

Some authors have not made a distinction between general cognitive behaviors and those relative to reproduction, choosing instead to consider behaviours related to 'reproduction' as physical and nothing more (McCarthy \& Konkle, 2005).

Notwithstanding, limbic system function relative to reproduction exists, and from flies to mice and rats, sex behavior is controlled to match the reproductive capacity of each individual and the availability of resources (Lenschow \& Lima, 2020).

If we separate general behavior from behavior relevant to reproduction and maintain the reproductive axis and specifically the limbic system as the center of gender identity relative to reproduction, then pubescent children who consistently, persistently, and insistently (Olson \& Gülgöz, 2018) maintain a gender opposite to that assigned at birth, and whose later reproductive behavior is not always conventional for their bodily sex, arguably makes the notion of a gender as purely social and a single category of sex/gender dubious. 
Accepting sexuality as the global term presented earlier in relation to reproduction and the differences in courtship, aggression, empathy, care of offspring as essential in reproduction, the significance of the reproductive axis, and especially the limbic system to gender identity becomes more evident. While there will be some overlap in behaviours related to reproduction, they are sufficiently canalized and polarized that average differences remain significant and relevant (McCarthy et al., 2017; Carothers \& Reiss, 2013).

\section{CONCLUSION}

This article presented gender identity as tethered to behavior relevant to the reproductive axis, hardwired into the subsystems of the frontal cortex and limbic system, and separate to higher-order executive functions.

Taken together, this article and studies in the transgender community provide substantial support for the endocrine and neurological differentiation of sex from sexual orientation from gender, and added support for their differential biological origins. 
Combined with our unique human consciousness and self-awareness, essential cognitive and emotional differences credibly make for our perpetual sense of gender, from which men and women adopt a gender role identity to express gender via gendered displays in their social world (West \& Zimmerman, 2009).

This article fits in well with current research into the bio-psycho-social origins of sex differences in the brain now more often attributed to the combined effects of hormones, genes, epigenetics, and the social environment (Ratnu et al., 2017) and favored as the line of thought in research into identity diversity.

Furthermore, regardless of causation, influences, or otherwise on transgender neurology, these studies highlight how gender is located in neurological networks of the reproductive axis independent to body sex. Additionally, the differential organization of the fetus and its brain must be managed or directed one way or another, or as Purves implied - bodily processes must be linked to neural differentiation (Purves, 1989). Because of the consecutive organization of body and brain, linking the two processes can be influenced 
independently, resulting in their miss-alignment or incongruence (Bao \& Swaab, 2011; Savic et al., 2010).

\section{Declaration of Interest Statement.}

This article does not contain any studies with human participants or animals performed by the author. 


\section{References}

Acevedo-Rodriguez, A., Kauffman, A.,

Cherrington, B., Borges, C., Roepke, T., \& Laconi, M. (2018). Emerging insights into hypothalamic-pituitary-gonadal axis regulation and interaction with stress signalling. Journal of neuroendocrinology, 30(10), e12590. Ahmed, S., Morrison, S., \& Hughes, I. (2004). Intersex and gender assignment; the third way? Archives of Disease in Childhood, 89, 847-850. Alzahrani, A., Ahmad, A., Alhazmi, T., \& Ahmad,

L. (2019). An Isolated Hypogonadotropic Hypogonadism due to a L102P Inactivating Mutation of KISS1R/GPR54 in a Large Family. Case Reports in Pediatrics, 2019. Arnold, A., Xu, J., Grisham, W., Chen, X., Kim, Y., \& Itoh, Y. (2004). Minireview: Sex chromosomes and brain sexual differentiation.

Endocrinology, 145(3), 1057-1062.

Bailey, J., Vasey, P., Diamond, L., Breedlove, S.,

Vilain, E., \& Epprecht, M. (2016). Sexual orientation, controversy, and science. Psychological Science in the Public Interest, 17(2), 45-101. 
Baldinger-Melich, P., Urquijo Castro, M., Seiger, R., Ruef, A., Dwyer, D., Kranz, G., Klobl, M., Kambeitz, J., Kaufmann, U., Windischberger, C., Kasper, S., Falkai, P., Lanzenberg, R., Koutsouleris, N. (2020). Sex matters: a multivariate pattern analysis of sex-and genderrelated neuroanatomical differences in cis-and transgender individuals using structural magnetic resonance imaging. Cerebral Cortex, 30(3), 1345-1356.

Bao, A., \& Swaab, D. (2011). Sexual differentiation of the human brain: Relation to gender identity, sexual orientation and neuropsychiatric disorders. Frontiers in Neuroendocrinology, 32, 214-226.

Bartky, S. (1999). Femininity and domination. In C. C. Gould (Ed.), Key concepts in theory:

Gender. New York: Humanity Books.

Batrinos, M. (2012). Testosterone and aggressive behaviour in man. International journal of endocrinology and metabolism, 10(3), 563. Bègue, I., Adams, C., Stone, J., \& Perez, D. (2019).

Structural alterations in functional neurological disorder and related conditions: a software and hardware problem?. NeuroImage: Clinical, 101798. 
Beking, T., Burke, S. Geuze, R., Staphorsius, A., Bakker, J., Groothuis, A. G., \& Kreukels, B. (2020). Testosterone effects on functional amygdala lateralization: A study in adolescent transgender boys and cisgender boys and girls. Psychoneuroendocrinology, 111, 104461.

Blair, J., McGee, H., Bhatta, S., Palm, R., \&

Casadesus, G. (2015). Hypothalamic-pituitarygonadal axis involvement in learning and memory and Alzheimer's disease: more than "just" estrogen. Frontiers in Endocrinology, 6, 45.

Bonelli, R., \& Cummings, J. (2007). Frontalsubcortical circuitry and behaviour. Dialogues in clinical neuroscience, 9(2), 141.

Buss, D. (1995). Evolutionary Psychology: A new paradigm for psychological sciences.

Psychological Enquiry, 6, 1-30.

Butler, J. (1990). Gender trouble. Feminism and the Subversion of Identity. New York, NY. Routledge. 
Card, N., Stucky, B., Sawalani, G., \& Little, T.

(2008). Direct and indirect aggression during childhood and adolescence: A meta-analytic review of gender differences, intercorrelations, and relations to maladjustment. Child development, 79(5), 1185-1229.

Cardinal, R, Parkinson, J, Hall, J, \& Everitt, B. (2002). Emotion and motivation: the role of the amygdala, ventral striatum, and prefrontal cortex. Neuroscience \& Biobehavioural Reviews, 26(3), 321-352

Carothers, B., \& Reiss, H. (2013). Men and women are from earth: Examining the latent structure of gender. Journal of Personality \& Social Psychology, 104, 2, 385-407. doi: 10 1037/a0030437

Chapman, E., Baron-Cohen, S., Auyeung, B., Knickmeyer, R., Taylor, K., \& Hackett, G. (2006). Fetal testosterone and empathy: evidence from the empathy quotient (EQ) and the "reading the mind in the eyes" test. Social Neuroscience, 1(2), 135-148.

Chen, P., Hu, R., Wu, Y., Pan, L., Huang, S., Micevych, P., \& Hong, W. (2019). Sexually dimorphic control of parenting behavior by the medial amygdala. Cell, 176(5), 1206-1221. 
Chodorow, N. (1999). The reproduction of

mothering: Psychoanalysis and the sociology of gender. Univ of California Press.

Cohen-Bendahan, C., Buitelaar, J., Van Goozen, S.,

Orlebeke, J., \& Cohen-Kettenis, P. T. (2005). Is there an effect of prenatal testosterone on aggression and other behavioural traits? A study comparing same-sex and opposite-sex twin girls. Hormones and Behaviour, 47(2), 230-237.

Cooke, B., Stokas, M, \& Woolley, C. (2007).

Morphological sex differences and laterality in the prepubertal medial amygdala. Journal of Comparative Neurology, 501(6), 904-915.

Couse, J., Yates, M., Walker, V., \& Korach, K. S. (2003). Characterization of the hypothalamicpituitary-gonadal axis in estrogen receptor (ER) null mice reveals hypergonadism and endocrine sex reversal in females lacking ER $\alpha$ but not ERß. Molecular Endocrinology, 17(6), 10391053.

de Vries, G., \& Södersten, P. (2009). Sex differences in the brain: the relation between structure and function. Hormones and behaviour, 55(5), 589-596. 
Del Giudice, M., Booth, T., \& Irwing, P. (2012).

The distance between Mars and Venus:

Measuring global sex differences in personality. PloS one, 7(1).

Denley, M., Gatford, N., Sellers, K., \& Srivastava,

D. (2018). Estradiol and the development of the cerebral cortex: an unexpected role?. Frontiers in neuroscience, 12, 245.

Diamond, M. (2013). Transsexuality among twins: identity concordance, transition, rearing, and orientation. International Journal of Transgenderism, 14(1), 24-38.

Dulac, C., O’Connell, L., \& Wu, Z. (2014). Neural control of maternal and paternal behaviours. Science, 345(6198), 765-770.

Eagly, A., \& Wood, W. (2013). The nature-nurture debates: 25 years of challenges in understanding the psychology of gender. Perspectives on Psychological Science, 8(3), 340-357. 
Fernández, R., Guillamon, A., Cortés-Cortés, J., Gómez-Gil, E., Jácome, A., Esteva, I., Almaraz, M., Mora, M., Aranda, G., \& Pásaro, E. (2018). Molecular basis of Gender Dysphoria: androgen and estrogen receptor interaction. Psychoneuroendocrinology, 98, 161-167.

Fiani, C. (2018). Beyond the Binary: Gender Identity and Mental Health Among Transgender and Gender Non-Conforming Adults. CUNY Academic Works.

Freud, S. (1966). Project for a scientific psychology (1950 [1895]). In The Standard Edition of the Complete Psychological Works of Sigmund Freud, I (1886-1899): Pre-Psycho-Analytic Publications and Unpublished Drafts , 281391.

Gilligan, C. (1993). In a different voice. Harvard University Press.

Gliske, S. (2019). A new theory of gender dysphoria incorporating the distress, social behavioural, and body-ownership networks. ENeuro, 6(6). 
Gouveia, F., Hamani, C., Fonoff, E., Brentani, H., Alho, E.., De Morais, R., de Souza, A., Rigonatti, S., \& Martinez, R. (2019). Amygdala and Hypothalamus: Historical Overview With Focus on Aggression. Neurosurgery, 85(1), 1130.

Grabowska, A. (2017). Sex on the brain: Are gender-dependent structural and functional differences associated with behaviour?. Journal of neuroscience research, 95(1-2), 200-212. Guillamon, A., Junque, C., \& Gómez-Gil, E. (2016). A review of the status of brain structure research in transsexualism. Archives of Sexual Behaviour, 45(7), 1615-1648.

Heberlein, A., Padon, A., Gillihan, S., Farah, M., \& Fellows, L. (2008). Ventromedial frontal lobe plays a critical role in facial emotion recognition. Journal of cognitive neuroscience, 20(4), 721-733.

Hewitt, J., Paul, C., Kasiannan, P., Grover, S.,

Newman, L., \& Warne, G. (2012). Hormone treatment of gender identity disorder in a cohort of children and adolescents. Medical Journal of Australia, 196(9), 578-581. 
Hines, M. (2017). Gonadal Hormones and Sexual Differentiation of Human Brain and Behaviour. Hormones, Brain, and Behaviour, 3(5), 247-278, doi.org/10.1016/B978-0-12-803592-4.00103-6

Hoekzema, E., Barba-Müller, E., Pozzobon, C., Picado, M., Lucco, F., García-García, D., Soliva, J., Tobeña, A., Desco, M., Crone, E., \& Ballesteros, A. (2017). Pregnancy leads to long-lasting changes in human brain structure. Nature Neuroscience, 20(2), 287.

Hoffmann, M. (2013). The human frontal lobes and frontal network systems: an evolutionary, clinical, and treatment perspective. ISRN neurology, 2013.

https://academicworks.cuny.edu/gc_etds/2815 Huber, R., \& Kravitz, E. (2010). Aggression: towards an integration of gene, brain and behaviour. Social behaviour: Genes, ecology and evolution, 165-180.

Hyde, J. (2005). The gender similarities hypothesis. American psychologist, 60(6), 581. 
Hyde, J., Bigler, R., Joel, D., Tate, C., \& Anders, S.

(2018). The future of sex and gender in psychology: Five challenges to the gender binary. The American psychologist. incongruence. International Review of Psychiatry, 28(1), 120-128.

Joel, D. (2011). Male or female? Brains are intersex. Frontiers of Intergretive Neuroscience, 5, 1-9. doi: 10 3389/fnint 2011 00057

Joel, D., \& Fausto-Sterling, A. (2016). Beyond sex differences: new approaches for thinking about variation in brain structure and function. Philosophical Transactions of the Royal Society B: Biological Sciences, 371(1688), 20150451. Joel, D., \& McCarthy, M. (2017). Incorporating sex as a biological variable in neuropsychiatric research: where are we now and where should we be?. Neuropsychopharmacology, 42(2), 379.

Joel, D., Garcia-Falgueras, A., \& Swaab, D. (2020). The complex relationships between sex and the brain. The Neuroscientist, 26(2), 156-169.

Jones, R., \& Lopez, K. (2014). Human reproductive biology. Chapter Sixteen. Academic Press. 
Kaiser, A. (2012). Re-conceptualizing "sex" and "gender" in the human brain. Zeitschrift für Psychologie.

Kawakami, M., Seto, K., Terasawa, E., \& Yoshida, K. (1967). Mechanisms in the limbic system controlling reproductive functions of the ovary with special reference to the positive feedback of progestin to the hippocampus. In Progress in brain research, 27, 69-102. Elsevier.

Klein C.(2003). The Hypothalamic-PituitaryGonadal Axis. In: Kufe D, Pollock R, Weichselbaum R, et al., editors. Holland-Frei Cancer Medicine. 6th edition. Hamilton (ON): BC Decker. Available from:

https://www.ncbi.nlm.nih.gov/books/NBK1338 6/

Kopsida, E., Stergiakouli, E., Lynn, P., Wilkinson, L., \& Davies, W. (2009). The role of the Y chromosome in brain function. Open neuroendocrinology journal (Online), 2, 20.

Kret, M., \& De Gelder, B. (2012). A review on sex differences in processing emotional signals. Neuropsychologia, 50(7), 1211-1221. 
Kreukels, B., \& Guillamon, A. (2016).

Neuroimaging studies in people with gender incongruence. International Review of Psychiatry, 28(1), 120-128.

Kruijver, F., Zhou, J., Pool, C., Hofman, M., Gooren, L., \& Swaab, D. (2000). Male-tofemale transsexuals have female neuron numbers in a limbic nucleus. The Journal of Clinical Endocrinology \& Metabolism, 85(5), 2034-2041.

Kuiri-Hänninen, T., Sankilampi, U., \& Dunkel, L. (2014). Activation of the hypothalamicpituitary-gonadal axis in infancy: minipuberty. Hormone research in paediatrics, 82(2), 73-80.

Kurtoğlu, S., \& Baştuğ, O. (2014). Mini puberty and its interpretation. Turkish Archives of Pediatrics/Türk Pediatri Arşivi, 49(3), 186. Legato, M. (2018). Untangling the Gordian Knot of Human Sexuality: What Is the Biologic Basis of Variations in Sexual Phenotype?. Gender and the Genome, 2(3), 62-67.

Leinbach, M., \& Fagot, B. (1986). Acquisition of gender labels: A test for toddlers. Sex Roles, 15(11-12), 655-666. 
Lenschow, C., \& Lima, S. (2020). In the mood for sex: Neural circuits for reproduction. Current Opinion in Neurobiology, 60, 155-168.

Leon, I. (2008). Psychology of reproduction:

Pregnancy, parenthood, and parental ties. Global Library of Women's Medicine.

Maccoby, E., \& Jacklin, C. (1974). The Psychology

of Sex Differences. Stanford, CA: Stanford University Pres.

Manzouri, A., Kosidou, K., \& Savic, I. (2017).

Anatomical and functional findings in femaleto-male transsexuals: testing a new hypothesis. Cerebral cortex, 27(2), 998-1010.

Marwha, D., Halari, M., \& Eliot, L. (2017). Metaanalysis reveals a lack of sexual dimorphism in human amygdala volume. Neuroimage, 147, 282-294.

McCarthy, M., \& Konkle, A. (2005). When is a sex difference not a sex difference?. Frontiers in neuroendocrinology, 26(2), 85-102.

McCarthy, M., Arnold, A., Ball, G., Blaustein, J., \& De Vries, J. (2012). Sex differences in the brain: the not so inconvenient truth. Journal of Neuroscience, 32(7), 2241-2247 
McCarthy, M., De Vries, G., \& Forger, N. (2017).

Sexual differentiation of the brain: a fresh look at mode, mechanisms, and meaning. Hormones, Brain and Behaviour (Third Edition), 5, 3-32. doi: 10.1016/B978-0-12-803592-4.00091-2

McEwen, B. (2001). Invited review: Estrogens effects on the brain: multiple sites and molecular mechanisms. Journal of applied physiology, 91(6), 2785-2801.

Meyer-Bahlburg, H. (2019). "Diagnosing” Gender?

Categorizing Gender-Identity Variants in the Anthropocene. Archives of sexual behaviour, 19.

Mhaouty-Kodja, S., Naulé, L., \& Capela, D. (2018). Sexual behaviour: from hormonal regulation to endocrine disruption. Neuroendocrinology, 107(4), 400416.

Mustanski, B., DuPree, M., Nievergelt, C., Bocklandt, S., Schork, N., \& Hamer, D. (2005). A genomewide scan of male sexual orientation. Human genetics, 116(4), 272-278 
Newman, S. (1999). The medial extended amygdala in male reproductive behaviour a node in the mammalian social behaviour network. Annals of the New York Academy of Sciences, 877(1), 242-257.

Olson, K., \& Gülgöz, S. (2018). Early findings from the transyouth project: Gender development in transgender children. Child Development Perspectives, 12(2), 93-97.

Owen-Blakemore, J., Berenbaum, S., \& Liben, L.

(2009). Gender development. New York:

Psychology Press.

Oxley, G., \& Fleming, A. (2000). The effects of medial preoptic area and amygdala lesions on maternal behaviour in the juvenile rat. Developmental Psychobiology: The Journal of the International Society for Developmental Psychobiology, 37(4), 253-265.

Pavlova, M. (2017). Sex and gender affect the social brain: beyond simplicity. Journal of Neuroscience Research, 95(1-2), 235-250. Pearson, R., Lightman, S., \& Evans, J. (2009).

Emotional sensitivity for motherhood: late pregnancy is associated with enhanced accuracy to encode emotional faces. Hormones and Behaviour, 56(5), 557-563. 
Perrin, P., Heesacker, M., Tiegs, T., Swan, L., Lawrence, A., Smith, M., Carrillo, R., Cawood, R., \& Mejia-Millan, C. (2011). Aligning Mars and Venus: The social construction and instability of gender differences in romantic relationships. Sex Roles, 64(9-10), 613-628. Pfaff, D. (2011). Man and woman: An inside story. New York: Oxford.

Purves, D. (1989). Body and brain: A trophic theory of neural connections. Harvard University Press.

Ratnu, V., Emami, M., \& Bredy, T. (2017). Genetic and epigenetic factors underlying sex differences in the regulation of gene expression in the brain. Journal of neuroscience research, 95(1-2), 301-310.

Reber, J., \& Tranel, D. (2017). Sex differences in the functional lateralization of emotion and decision making in the human brain. Journal of neuroscience research, 95(1-2), 270-278.

Rice, W., Friberg, U., \& Gavrilets, S. (2012).

Homosexuality as a consequence of epigenetically canalized sexual development. The Quarterly review of biology, 87(4), 343368. 
Rippon, G. (2017). Culture not biology is behind many differences between the sexes. New

Scientist. https://www. newscientist.

com/article/2144424-culture-not-biology-isbehind-many-differences-between-the-sexes.

Rippon, G., Jordan-Young, R., Kaiser, A., \& Fine,

C. (2014). Recommendations for sex/gender

neuroimaging research: key principles and implications for research design, analysis, and interpretation. Frontiers in human

neuroscience, $8,650$.

Ristori, J., Cocchetti, C., Romani, A., Mazzoli, F.,

Vignozzi, L., Maggi, M., \& Fisher, A. (2020).

Brain Sex Differences Related to Gender

Identity Development: Genes or

Hormones?. International Journal of Molecular

Sciences, 21(6), 2123.

Ritchie, S., Cox, S., Shen, X., Lombardo, M., Reus,

L., Alloza, C., Harris, M., Alderson, H.,

Hunter, S., Neilson, E., Liewald, D, Auyeung,

B., Whailey, H., Lawrie, S., Gale, C., Bastin,

M., McIntosh, A., Deary, I. (2018). Sex

differences in the adult human brain: evidence from 5216 UK biobank participants. Cerebral Cortex, 28(8), 2959-2975. 
Rogol, A. (2020). Human sex chromosome aneuploidies: The hypothalamic-pituitarygonadal axis. In American Journal of Medical Genetics Part C: Seminars in Medical Genetics. Hoboken, USA: John Wiley \& Sons, Inc.

Roselli, C. (2018). Neurobiology of gender identity and sexual orientation. Journal of neuroendocrinology, 30(7), e12562. Roxo, M., Franceschini, P., Zubaran, C., Kleber, F.., \& Sander, J. (2011). The limbic system conception and its historical evolution. The scientific world journal, 11, 2427-2440.

Sakata, J., \& Crews, D. (2004). Developmental sculpting of social phenotype and plasticity. Neuroscience \& Biobehavioural Reviews, 28(2), 95-112.

Sánchez, F., \& Vilain, E. (2013). Transgender identities: Research and controversies. In C. J. Patterson \& A. R. D'Augelli (Eds.), Handbook of psychology and sexual orientation (p. 4254). Oxford University Press

Sato, T., Matsumoto, T., Kawano, H., Watanabe, T., Uematsu, Y., Sekine, K., Fukuda, T., Aihara, K., Krust, A., Yamada, T., \& Nakamichi, Y., 
(2004). Brain masculinization requires androgen receptor function. Proceedings of the National Academy of Sciences, 101(6), 1673-1678.

Savic, I., Garcia-Falgueras, A., \& Swaab.D. (2010). Sexual differentiation of the human brain in relation to gender identity and sexual orientation, Progress in Brain Research, 186,41-62.

Serano, J. (2016). Whipping Girl: A Transsexual Woman on Sexism and the Scapegoating of Femininity. Berkley, Seal Press.

Simerly, R. (2010). Sexual Differentiation of the Central Nervous System. In G. Lemke, (Ed.). Developmental neurobiology. Academic Press. Simerly, R. (2002). Wired for reproduction: organization and development of sexually dimorphic circuits in the mammalian forebrain. Annual review of neuroscience, 25(1), 507-536

Sisk, C. (2016). Hormone-dependent adolescent organization of socio-sexual behaviours in mammals. Current opinion in neurobiology, 38, 63-68. 
Smith, E., Junger, J., Derntl, B., \& Habel, U.

(2015). The transsexual brain-A review of findings on the neural basis of transsexualism.

Neuroscience \& Biobehavioural Reviews, 59, 251-266.

Sokolowski, K., \& Corbin, J. (2012). Wired for behaviours: from development to function of innate limbic system circuitry. Frontiers in molecular neuroscience, 5, 55.

Stam, D., Huang, Y., \& Van den Stock, J. (2019).

Non-overlapping and Inverse Associations

Between the Sexes in Structural Brain-Trait Associations. Frontiers in psychology, 10, 904.

Steensma, T., McGuire, J., Kreukels, B., Beekman, A., \& Cohen-Kettenis, P. (2013). Factors associated with desistence and persistence of childhood gender dysphoria: a quantitative follow-up study. Journal of the American Academy of Child \& Adolescent Psychiatry, 52(6), 582-590

Strauss, P., Cook, A., Winter, S., Watson, V., Wright Toussaint, D., Lin, A. (2017). Trans Pathways: the mental health experiences and care pathways of trans young people. Summary of results. Telethon Kids Institute, Perth, Australia. 
Sundermann, E., Maki, P., \& Bishop, J. (2010). A review of estrogen receptor $\alpha$ gene (ESR1) polymorphisms, mood, and cognition. Menopause (New York, NY), 17(4), 874.

Swaab, D. (2004). Sexual differentiation of the human brain: relevance for gender identity, transsexualism and sexual orientation. Gynecological

Endocrinology, 19(6), 301-312.

Swaab, D., \& Garcia-Falgueras, (2009). Sexual differentiation of the human brain in relation to gender identity and sexual orientation.

Functional Neurology, 24(1), 17.

Swain, J., Lorberbaum, J., Kose, S., \& Strathearn, L. (2007). Brain basis of early parent-infant interactions: psychology, physiology, and in vivo functional neuroimaging studies. Journal of child psychology and psychiatry, 48(3-4), 262-287. 
Sweatt, J., Nestler, E., Meaney, M., \& Akbarian, S. (2013). An overview of the molecular basis of epigenetics. In: J. Sweatt, M. Meaney, \& E.

Nestler (Eds.), Epigenetic regulation in the

nervous system: Basic mechanisms and clinical impact. Academic Press. doi: 10 1016/B978-012-391494-1 00001-X

Tasopoulos, C. (2018). Human Sexual

Differentiation and Aberration

Spectrum. Encephalos, 55, 25-29.

Tay, P., Ting, Y., \& Tan, K. (2019). Sex and Care:

The evolutionary psychological explanations for sex differences in formal care occupations. Frontiers in psychology, 10, 867. Temple Newhook, J., Pyne, J., Winters, K., Feder, S., Holmes, C., Tosh, J., Sinnott, M., Jamieson, A., \& Pickett, S. (2018). A critical commentary on follow-up studies and "desistance" theories about transgender and gender-nonconforming children. International Journal of Transgenderism, 19(2), pp.212-224. 
Tunç, B., Solmaz, B., Parker, D., Satterthwaite, T., Elliott, M., Calkins, M., Ruparel, K., Gur, R., Gur, R., \& Verma, R. (2016). Establishing a link between sex-related differences in the structural connectome and behaviour. Philosophical Transactions of the Royal Society B: Biological Sciences, 371(1688), 20150111.

Unger, E., Burke Jr, K., Yang, C., Bender, K., Fuller, P., \& Shah, N. (2015). Medial amygdalar aromatase neurons regulate aggression in both sexes. Cell reports, 10(4), 453-462.

van Anders, S. (2015). Beyond sexual orientation: Integrating gender/sex and diverse sexualities via sexual configurations theory. Archives of Sexual Behaviour, 1-37.

West, C., \& Zimmerman, D. (2009). Accounting for doing gender. Gender \& society, 23(1), 112122. 
Whittle, S., Barendse, M., Pozzi, E., Vijayakumar, N., \& Simmons, J. (2020). Pubertal hormones predict sex-specific trajectories of pituitary gland volume during the transition from childhood to adolescence. NeuroImage, 204, 116256.

Whittle, S., Yücel, M., Yap, M., \& Allen, N.

(2011). Sex differences in the neural correlates of emotion: evidence from neuroimaging. Biological psychology, 87(3), 319-333.

Weigel, N., Vodolaga, V., Shapoval, G.,

Kartashova, E., \& Safronenko, A. (2020).

Modern Androgyny as a Manifestation of a Universal Personality. Journal of Talent

Development and Excellence, 12(3s), 234-241. Xu, X., Coats, J., Yang, C., Wang, A., Ahmed, O., Alvarado, M., Izumi. T., \& Shah, N. (2012). Modular genetic control of sexually dimorphic behaviours. Cell, 148(3), 596-607.

Yang, L., Comninos, A., \& Dhillo, W. (2018).

Intrinsic links among sex, emotion, and reproduction. Cellular and molecular life sciences, 75(12), 2197-2210. 
Yao, S., Bergan, J., Lanjuin, A., \& Dulac, C.

(2017). Oxytocin signaling in the medial amygdala is required for sex discrimination of social cues. Elife, 6, e31373.

Zaidi, Z. (2010). Gender differences in human brain: a review. The open anatomy journal, 2(1).

Zell, E., Krizan, Z., \& Teeter, S. (2015). Evaluating gender similarities and differences using metasynthesis. American Psychologist, 70(1), 10.

Zietsch, B., Morley, K., Shekar, S., Verweij, K., Keller, M., Macgregor, S., Wright, M., Bailey, J., \& Martin, N. (2008). Genetic factors predisposing to homosexuality may increase mating success in heterosexuals. Evolution and Human Behaviour, 29(6), 424-433.

Zucker, K. (2018). The myth of persistence:

Response to "A critical commentary on followup studies and 'desistance'theories about transgender and gender non-conforming children" by Temple Newhook et al.(2018). International Journal of Transgenderism, 19(2), 231-245. 
Zucker, K., Bradley, S. J., \& Sanikhani, M. (1997).

Sex differences in referral rates of children with gender identity disorder: Some hypotheses.

Journal of Abnormal Child Psychology, 25(3), 217-227.

Zuloaga, D., Jordan, C., \& Breedlove, M. (2010). Sexual Differentiation of the Brain. In G. Lemke, (Ed.). Developmental neurobiology. Academic Press. 